\title{
Introduction to the Special Issue on Female Migration to ISIS
}

\author{
Emilio C. Viano* \\ Editor in Chief, International Annals of Criminology \\ ${ }^{*}$ Corresponding Author: Emilio C. Viano, International Society of Criminology, PO Box 58186, \\ Washington, DC 20037, USA. E-mail: emilio.viano@gmail.com
}

(Submitted 17 November 2017; revised 3 April 2018; accepted 9 June 2018)

\begin{abstract}
Terrorism, while not new in the history of humanity, has become a major issue and challenge for contemporary society worldwide. Recently it has become embodied and symbolized by the "Islamic State in Iraq and Syria" (ISIS) in its many permutations in the Middle East, the focus of massive military intervention on the part of major world powers and of study, analysis, strategy and planning. One aspect that has distinguished ISIS from previous terrorist movements is a major migration of women, especially but not limited to Western Europe, joining the jihad proclaimed by the religious leaders of ISIS. This introduction to the special issue on Female Migration to ISIS surveys and identifies the known possible roots of the phenomenon and related issues, summarizes major known points relative to it, and outlines the future agenda of work, not only academic but also practical and strategic, to be followed. Balanced recommendations on how to build a promising intervention strategy not only based on military force are put forth for consideration and discussion. While based on research, this article should be considered more of an editorial, generally introducing the field, summarizing existing work, especially the content of this special issue, and pointing out work needed in the future.
\end{abstract}

Keywords ISIS; female recruitment; motivation; oppression of Muslims; Caliphate; alienation; isolation; repatriation; interventions

A recent phenomenon that has attracted much attention and concern has been the successful female recruitment drives in Western Europe and other "Western" countries by the "Islamic State in Iraq and Syria" (ISIS) in its various permutations.

While many types of terrorist movements in history have been driven by local grievances, leaders and funding, ISIS has clearly been from the beginning an international organization attracting participation from many regions in the world, including Europe. Additionally, an especially novel aspect of the recruiting and staffing of ISIS has been the considerable number of women who have decided to join it and have migrated from their country of birth or residence to areas conquered and controlled by ISIS. At times these women accompany their husbands to the combat 
zone. This may include children as well, that is, the entire family. Women are often traveling to the combat zones because of their present or intended relationship with a male fighter. This migration has raised serious concern particularly on the part of Western governments that anticipate the possible return of these people to their original place of residence, bringing back home fighting, bomb making, and attack planning skills along with radicalization and combat experience; in other words, bringing the jihad back into Western Europe with the likelihood of spectacular and damaging terrorist acts. There are also women who migrated to ISIS territory alone, motivated by different reasons and priorities, ranging from the romantic ideal of marrying a "lion," that is, a combatant for the faith, to earning a well-rewarded eternal life.

This group has received the most attention on the part of the media, governments and the public, especially when the women are minors, very young and raised in a Western culture and system of education. A major concern is that these young women may be trafficked through a well-organized system of recruitment, travel and handling until they reach ISIS-controlled territory; that they may be mistreated, abused, forcefully married to ISIS fighters or used as sex slaves; that at times they may be sidelined and driven into destitution especially if they are widowed; that they may be recruited or forced to join the fight, especially as suicide bombers; and that they may one day come back to sow terror at home.

\section{REASONS WHY WOMEN JOIN ISIS}

There is considerable discussion on why these women, especially those young and Western born, raised and educated, migrate to ISIS-held territory and join terrorist groups, leaving behind family, friends, a way of life, values and opportunities that are deemed to be among the best in the world. As with all types of extremism, the motives the women mention for taking off are as different as the women themselves are. However, five distinct and major reasons for traveling can be identified:

\section{(1) Oppression of the Muslims}

The first is the oppression of the Muslims, and the alleged war by Western powers against them. The "Ummah under attack" is a powerful motivator for these women, especially at an impressionable age. They can recount and enumerate a long list of aggressions, past and present, all over the world from Bosnia to Syria, from Yemen to Myanmar. Appalling photographs of children hurt by the attacks, like recently in Yemen on a school bus, who lost limbs or are seriously disfigured, are frequently published on Twitter profiles and on blogs. Many conflicts in various parts of the world are conflated into the widely held belief that Western powers are at war with Islam. The world is described in black and white, in binary terms as if there are two clearly defined opposing entities in an epic struggle with one another: the camp of the imam (that is, belief) versus the camp of the kefir (that is, unbelief). The sympathy that these women express for Muslim victims of aggression and the collusion they believe Western countries have in starting and continuing these clashes are crucial reasons for their choice to leave the West, look for a different society, and clash with the West as an opponent to be vanquished. 


\section{(2) Building the Caliphate}

Women who migrate to ISIS are not only rejecting Western values, culture and way of life. They also have a positive objective. This is to introduce and make real a new conception and vision of society and what it stands for.

Many of the migrant women are drawn by a combination of fantasy and the feeling that, by joining ISIS, they will be empowered, have an exciting life, and do something meaningful with their lives. Their ambition is to contribute to establishing a society regulated by a strict understanding and enforcement of the Sharia law. These women yearn for a key role to play in state building, in constructing a new world inspired and governed by the Koran. They celebrate every victory, every territorial progress of ISIS and root for its success and triumph over Western values and way of life. For these women, the land controlled by ISIS is an alluring safehaven for those who intend to pursue Islam completely and conduct themselves by its rules; a place where they can live honorably under the Sharia; and advance the interests and the influence of the Ummah. ISIS is translating their idealized dream of an Islamic state into reality. As to themselves, these women want to help the establishment of an ideologically pure state and to contribute practically to ISIS's state building in various roles, as mothers, nurses, teachers and more. In other words, the declaration of the Caliphate on the part of ISIS is providing these women with a credible and pragmatic outlet, doing something concrete beyond only supporting ISIS online. This exercises a considerable power of attraction on women, especially when combat is off limits for them as it is under the strict interpretation of the Koran.

\section{(3) Individual Duty and Identity}

For these women, building a Muslim caliphate is not only something very desirable but an obligatory religious duty. In other words, they believe that building an Islamic state is a must for every Muslim. Migration then becomes an obvious duty. Completing these duties is essential to obtaining one's seat in heaven. A strong belief in the afterlife is a powerful motivating variable both for the ISIS men in combat and for the women in a supportive role. Thus, the migration from an infidel Western country to a pure Islamic state is seen as moving to the threshold of heaven.

\section{(4) Earthly Rewards. Marriage}

The rewards to be received are not limited to heavenly ones. There are rewards to be received on this earth as well. Foremost among female supporters of ISIS is the romantic idea of marrying a brave and noble warrior. Marriage for many women represents the passage from childhood into adulthood, especially in cultures that tightly control women's lives. Thus, it is a core factor in spurring female migration to ISIS land. Women traveling to Syria and Iraq and expecting to remain single and independent do not fit well there. They are out of place and quite vulnerable. But this is not limited only to marriage. By going to ISIS land to help support the conquest of more territory and establishing a pure state, the women find camaraderie, sisterhood, enthusiasm and warmth at a level hardly possible in the West, which is perceived as superficial and exploitative. Meaning in life, identity and sisterhood are powerful motivators for these migrating women. 


\section{(5) Alienation and Isolation}

The perceived failure of Western states to give Muslims a sense of belonging, purpose and value as Muslims and as citizens is striking in the online accounts of women jihadist studied to date. ${ }^{1}$ Women who migrate to ISIS are motivated by serious grievances because of the perceived mistreatment of Muslims around the world, underlined and confirmed by the foreign policy of the West. To address these problems, they have a solution: an Islamic society founded on the strict, fundamentalist interpretation and application of Sharia law. They share in common a view of the prototypical society that they want to introduce in the ISIS-held areas. Additionally, these women consider that migrating is their religious duty and see it as a sure way to get closer to God and to attain a place in heaven. A romantic view of the ISIS "lions" and a strong attraction to sharing a glorious adventure with them through marriage are also motivators.

\section{INTERVENTION}

In order to effectively intervene and stop this migration to ISIS or to any of its successors now or in the future it is necessary to discuss and develop a strategy to prevent the migration of women to ISIS territory or similar; dissuade them from joining a terrorist group; and inoculate them from messages meant to induce them to leave their family, career, loved ones and more to join the fighting there. The main objectives of this effort, reflected in many of the articles in this special issue of the International Annals of Criminology, are:

First, to review as much as possible the reasons why women consider joining ISIS and their experience. It is only by understanding the motivations and experiences of those who have gone to fight abroad that we can prevent the recruitment of another generation of terrorists.

Second, to devise and build a well-focused, pragmatic and effective plan to counteract the recruitment, persuasion and seduction exercised by ISIS or similar groups on women, especially very young ones, to migrate to its territory. This will require a detailed mapping and analysis of the mechanisms, dynamics, reasoning and enticements used by the recruiters to attract their recruits; convince them to forsake their families, friends, and the world that they have known; travel to ISIS (or similar)-controlled territory; and support the terrorist group in its quest for power, conquest and dominance.

It is also essential to focus on how to respond to the tactics used by ISIS and how to neutralize and counteract its messages. For example, an approach to be carefully studied involves three Ds: delegitimize, deglamorize and demobilize. ${ }^{2}$ This entails showing what involvement in terrorism is actually like and, in the process, how it undermines the basis upon which women (and men) involve themselves with it. To counteract its attractiveness, it is important to stress that the savage violence practiced by ISIS is not sanctioned by the Koran or the Hadith. The glamor often connected with ISIS and its war exploits must be unmasked. A good way to do so is to have women who escaped from ISIS tell their stories, showing how they became

\footnotetext{
${ }^{1}$ See, for example, the work of Katherine Brown, Defence Studies, King's College, London (Brown 2015).

${ }^{2}$ The use of the so-called three Ds to address how to respond to ISIS tactics frequently appears in academic, policy and professional writings, position papers and action-oriented recommendations. See, for example, Fenstermacher and Leventhal (2011).
} 
disillusioned and why. The media are too often glamorizing terrorism and terrorists, ironically by depicting them as extremely evil but also as quite powerful and to be deeply feared. ISIS has dramatically supported this vision of itself through gruesome, violent, inhumane executions of its prisoners and hostages. There is no question that the visual depictions of the amputations, stoning, crucifixions, decapitations, burning people alive, mass executions, and destruction of churches and museums cause revulsion, horror and "terror" at the realization of the brutality of this group and its willingness to use it, openly defying standards of decency and any notion of human rights and freedoms. At the same time, this fear and terror generate awe, respect and submission. Instead, ISIS and other terrorist groups should be deglamorized, shown to be corrupt, hypocritical and exploitative, especially of women. The story of how women who join ISIS are mostly used for sex, procreation and domestic service, and at times brutally assaulted, mistreated, forced to marry or sexually enslaved, abandoned and rejected, especially upon widowhood, must be told. According to experts, there are numerous "celebrity" ex-terrorists who can definitely help deglamorize and demythologize the terrorist lifestyle. As to women, detailing how women in the Middle East have often been forced or tricked to participate against their will in terrorist activities, including suicide bombing missions, is also important to unmask terrorist movements and show how exploitative and dismissing of women they are to the point, for example, of raping women to totally devalue them for marriage and a normal life so that they then agree, out of desperation and the realization that they are already socially dead, to accept suicide bombing missions as a way out of their impossible situation. This deglamorizing can be done also by stressing the devastation and total ruin caused by terrorist attacks against women and children and the appalling record of ISIS when it comes to women's rights and dignity. There is also a need to show and stress the futility of terrorism. Terrorists rarely, if ever, succeed in achieving their primary political or religious goals or in maintaining for a long time their control of territory and peoples. This is actually what happened to ISIS territorial holdings in the Middle East.

\section{EXIT AVENUES}

Another area of study and intervention is to identify and propose mechanisms and pathways for women to exit terrorist organizations. Few of the current de-radicalization programs (whose effectiveness is questioned) have programs or facilities especially designed with women and children in mind. However, it is the women and children who may give life and continuity to the conflict in the future. In other words, we need to address how to demobilize women returnees who may be "on call" to perpetrate terrorist attacks on the homeland. This task will not be easy since women are often more radical than men and quite a few are "true believers." The correct approach may have to focus less on beliefs and more on actions. This is a long-term effort to address the roots of the disenfranchising of women, often the consequence of racism, isolation and rejection. This is why disenfranchised women fall for the siren call of ISIS. Taking positive steps for their inclusion and advancement may make it possible to reduce and eventually eliminate the recruitment cycle. An important aspect of the program meant to counter the appeal of extremists and terrorists is also to address the teaching of Islam and which type of Islam in various countries. Approaching and enlisting the support of Muslim religious leaders to preach a moderate message of Islam and underline the 
positive things that the Koran says about women is essential. Women need to be empowered and to receive the means necessary to qualify as future leaders of their communities. They must be able to learn enough about Islam so that, in the future, no manipulative, cunning and devious group or leader can easily distort the holy text and convince them that the Koran legitimizes terrorism and mayhem.

\section{THE CLASSICAL 5DS}

The classical 5Ds ${ }^{3}$ (deterrence, denial, dissuasion, defense and diplomacy) must be attentively studied for possible utilization on this challenge. The goal is not to blindly apply conventional ideas but to look for flashes of insight from each to help produce new, effective ways to tackle the problem.

\section{Denial}

For example, in reference to "Denial," careful consideration should be given to how to stop the flow of information and communication between ISIS, its recruiters, the women who became members and potential followers in the West. The approval and praise of ISIS violence by women on their social media have the effect of strengthening and confirming ISIS propaganda. It also helps to increase favorable pro-ISIS sentiment online and motivates more women to follow the others to ISIS-controlled areas. Another example of possible denial is to forbid or at least tightly control international travel by unaccompanied minors, especially when the destination is the Middle East or a known terrorist-controlled area or at least to flag such travel to authorities for investigation.

\section{Defense}

"Defense" underlines the need to recognize the bigger menace stemming from the online presence of women who migrated to ISIS-held regions. This is a powerful tool and a strategic position for them to influence and motivate others, be they men or women to mount attacks against the West and/or to migrate to ISIS or other terrorist group land. They even resort to attacking and belittling those who "hide" behind family or other obligations to justify not traveling to ISIS territory. Their masculinity or commitment to Islam is put in doubt. Practical advice and information are also provided to those planning the journey to facilitate it. It has not been uncommon for these women to make themselves directly available by means of closed messaging apps or direct messaging.

\section{Dissuasion}

"Dissuasion" brings to mind an important fact: that schools have now become the main and most important frontline to intervene to stop young people, especially women, to be lured to travel to ISIS-held territory and to be forced into unlawful child marriages, which at times means that a young woman is sent to the Middle East

\footnotetext{
${ }^{3}$ This expression has been used in various permutations since a major speech by then UN Secretary General Kofi Annan in Madrid when he outlined a five-pillar strategy against terrorism (United Nations 2005). Various policy, expert and academic papers have used this expression in various forms to address how to respond to terrorism.
} 
or elsewhere to marry a combatant or a supporter of ISIS or similar. Dissuasion also requires well-designed mass media and social media campaigns.

\section{Diplomacy}

When it comes to "Diplomacy," our ability to protect the homeland hinges to a major degree on our capacity to establish international networks and introduce arrangements that can reinforce the capacity to act internationally and in a resilient manner. International security policies and structures have an impact on the international environment and facilitate preparedness at home.

\section{Deterrence}

"Deterrence" relates to discouraging this human traffic through the classical interventions of the criminal justice system, and also through the use of the media to project a powerful and well-crafted message that effectively discourages in various ways would-be joiners from even considering the journey. Deterrence is also essential in the case of women returnees. The death in combat or as a result of an aerial bombing of a spouse or partner may motivate a woman to return to the country of departure. There is no question that "dormant" returnees can present a serious threat. As the conflict continues, returnees may be affected if some of their comrades still with ISIS or similar are killed or ISIS is being defeated. On this basis, some women may become even more radicalized and get into a frenzy of activity. This is dangerous especially if they are acting under the radar of the security forces.

\section{EXAMPLES OF MEASURES TO BE TAKEN}

If society wants to limit and even eliminate the tide of female recruits to ISIS or similar, certain measures need to be taken. The ambitious goal of some of the material published here is to identify and present some of them. For example, electronic communications are the fundamental recruiting and radicalization tool reaching out to aspiring female migrants. It must be considered a key battleground where a vigorous pushback must take place. Providing a counter-narrative tailored to a female audience is especially important. Women who have migrated and are in touch with women back home or themselves return home are the best source of this counter-narrative. Advertising and messaging techniques will then facilitate these female-focused counter-narratives to reach high-risk women across different social media platforms. Such mass media and social media messages should be designed and tested in focus groups. It must be kept in mind that in these cultures the family has considerable influence on would-be migrants and is a more effective preventative organism than the state. Strengthening the ability of the family to respond and engage would-be recruits at the emotional rather than only at the intellectual level should be a major priority.

A path for the female migrant to return should be kept open. Threatening arrest and prison terms will discourage women from coming back, share actionable intelligence, and cooperate in the fight against ISIS and its recruitment campaign. The death of a husband or the birth of a child can trigger a desire to return that should not be discouraged by a penalty policy. A good example of using these dynamics positively was the media-circulated hash tag \#Nobodycaresaboutthewidow 
after a female migrant's husband was killed in action and she was totally ostracized and neglected.

\section{CONCLUSION}

As it was already stated, females migrate to ISIS-held areas for many reasons, hoping for comradeship; for ideological reasons; looking for adventure; or for an opportunity to marry a "lion." These women do pose a unique and serious threat to the West. However, to succeed in the long term, society's response must be refined, nuanced and carefully tailored. The lessons of the past decade about the sheer variety of factors that can lead people down the path to radicalization must be carefully learned and we must use fully the technology at our disposal. The media must also be invited to take part in this effort. Education specialists should craft much-needed curricular changes for primary and secondary schools. Religious Muslim leaders must be asked to contribute, especially when it comes to a more moderate approach to Islam. Female Muslim doctoral and law students should be especially encouraged to participate and to provide their unique and essential insights. The ISIS recruitment drive for women has played out in the same arena as it has for men: online. Consequently, it is in the same technological field where preventing and nullifying terrorist groups' recruitment campaigns is going to be fought. Moreover, online networks facilitate the travel of the recruits and help coordinate them with expatriate communities once they arrive, another technological target of intervention. The areas of research, intervention and follow-up on these issues open up many opportunities for scholars, professionals, practitioners and government officials to coordinate, cooperate and innovate. Originality, fine tuning in consonance with culture, religion and centuries-old values, and positive use of today's technological breakthroughs are the basic, essential instruments needed to tackle this challenge. That ISIS has been ostensibly defeated and has lost its territory in the Middle East is not a reason to stop working in this area. Permutations of ISIS and others are increasingly active in many regions of Africa, from Somalia to Chad, from Northern Nigeria to Libya. Asia, especially South Asia, is not immune. Europe and North America must continue to be alert and on the ready. Thus, the contribution of this special issue of the International Annals of Criminology to a reasoned discourse and innovative approaches on this continuing challenge is significant, current, on target and valuable. The Editor thanks all the authors for their willingness to share the outcome of years of hard work and pioneering research and interventions; for their patience awaiting for their work to appear in print; and for their continued commitment to help contain, defeat and solve this major current challenge, relying more on positive interventions and well-grounded persuasion than on continuing to count on military intervention and war as the choice solutions, a strategic error unfortunately repeated throughout the centuries.

Acknowledgements. The Editor, Emilio C. Viano, gratefully acknowledges the financial support of the Science for Peace and Security Programme of the North Atlantic Treaty Organization for the Advanced Research Workshop on Female Migration to ISIS held in Venice, Italy in 2016. International experts, researchers and professionals met there to share knowledge, insights and experiences on this issue and begin work on this project. The material published in this special issue is one of the outcomes of the project. The list of the participants appears at the end of this special issue. The support of the Salesian University Institute of Venice (IUSVE), of the General Investigations and Special Operations Division (DIGOS) of the Italian State Police, and of the City of Venice is recognized with sincere thanks. Moreover, the design of the website for the Female Migration to ISIS project by Sarah Alsaud is greatly appreciated. 


\title{
References
}

Brown, Katherine. 2015. “Katherine's Insight into Women in the Islamic State.” Retrieved August 30, 2018 (http://www.lancaster.ac.uk/alumni/news/archive/talk/katherines-insight-into-women-in-the-islamicstate/).

Fenstermacher, Laurie and Todd Leventhal (editors). 2011. Countering Violent Extremism: Scientific Methods \& Strategies. Fairborn, OH: Wright-Patterson Air Force Base. Retrieved September 16, 2018 (http://www.dtic.mil/dtic/tr/fulltext/u2/a552480.pdf).

United Nations. 2005. "Secretary-General Kofi Annan Launches Global Strategy against Terrorism in Madrid." Retrieved August 30, 2018 (https://www.un.org/press/en/2005/sg2095.doc.htm).

\section{Abstracto}

El terrorismo, aunque no es nuevo en la historia de la humanidad, se ha convertido en un problema y un desafío importante para la sociedad contemporánea en todo el mundo. Recientemente se ha encarnado y simbolizado por el ISIS en sus muchas permutaciones en el Medio Oriente, foco de la intervención militar masiva por parte de las principales potencias mundiales y de estudio, análisis, estrategia y planificación. Un aspecto que ha distinguido a ISIS de los movimientos terroristas anteriores es una importante migración de mujeres, originando especialmente de Europa Occidental para juntarse a la jihad proclamada por los líderes religiosos de ISIS. Esta introducción a este número especial sobre la migración femenina al ISIS encuesta e identifica las posibles raíces conocidas del fenómeno y cuestiones relacionadas, resume los principales puntos conocidos relativos a esta migración y describe la futura agenda de trabajo, no solo académica, sino también práctica y estratégica, para ser seguida. Se presentan recomendaciones equilibradas sobre cómo construir una estrategia prometedora de intervención no solo basada en la fuerza military, para consideración y discusión. Si bien se basa en la investigación, este artículo debe considerarse más como un editorial que introduce el campo por lo general; resumiendo el trabajo existente, especialmente el contenido de este número especial; y señalando el trabajo que se necesita en el futuro.

Palabras clave: ISIS; reclutamiento de mujeres; motivación; opresión de los musulmanes; califato; alienación; aislamiento; repatriación; intervenciones

\begin{abstract}
Abstrait
Le terrorisme, même s'il n'est pas nouveau dans l'histoire de l'humanité, est devenu un enjeu et un défi majeurs pour la société contemporaine dans le monde entier. Récemment, il a été incarné et symbolize surtout par ISIS dans ses nombreuses permutations au Moyen-Orient, au centre d'une intervention militaire massive des grandes puissances mondiales et d'étude, d'analyse, de stratégie et de planification. L'un des aspects qui distingue l'ISIS des mouvements terroristes antérieurs est une migration importante de femmes, en particulier mais pas exclusivement, provenant de l'Europe occidentale qui rejoint le djihad proclamé par les chefs religieux de l'Etat islamique. Cette introduction au numéro spécial sur la migration des femmes à ISIS identifie les racines connues possibles du phénomène et les questions connexes, résume les principaux points connus relatifs à elle et décrit le futur programme de travail, non seulement académique mais aussi pratique et stratégique. Des recommandations équilibrées sur la manière de mettre en place une stratégie d'intervention prometteuse, non seulement fondée sur la force militaire, sont proposées pour examen et discussion. Bien que basé sur la recherche, cet article devrait être considéré davantage comme un éditorial présentant généralement le
\end{abstract}


domaine; résumant des travaux existants, en particulier le contenu de ce numéro spécial; et soulignant le travail nécessaire dans le futur.

Mots-clés: ISIS; recrutement des femmes; motivation; oppression musulmane; califat; aliénation; isolement; rapatriement; interventions

抽象

恐怖主義雖然不是人類歷史上的新事物，但已成為全世界當代社會的一個主要問 題和挑戰。

最近, ISIS在中東的許多排列中體現和象徵著它，是世界主要大國以及研究， 分析，戰略和規劃的大規模軍事干預的焦點。將伊斯蘭國與以前的恐怖主義運動 區別開來的一個方面是婦女的重大移民，特別是但不限於西歐，加入了伊斯蘭國 宗教領袖宣布的聖戰。介紹了關於女性移民到ISIS調查的特刊，並確定了該現象 和相關問題的已知可能根源, 總結了與此相關的主要已知要點, 並概述了未來的 工作議程, 不僅是學術性的, 而且是實踐性和戰略性的。, 被關注。

關於如何建立一個不僅基於軍事力量的有前景的干預戰略的平衡建議被提出供 審議和討論。雖然基於研究，本文應該更多地被視為一般性介紹該領域的社論;總 結現有工作，特別是本期特刊的內容;並指出未來需要的工作。

關鍵詞 伊斯蘭國，女性招募，動機，穆斯林壓迫，哈里發，異化，孤立，遣返，干預

$$
\text { ملخص موجز الإنسانية ، قضية رئيسية وتحديا للمجتمع المعاصر في جميع أنحاء العالم }
$$

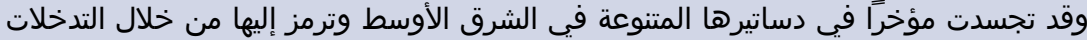

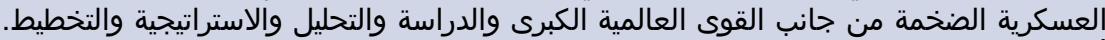

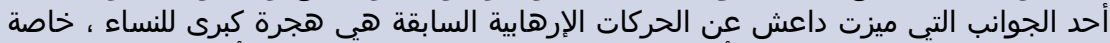

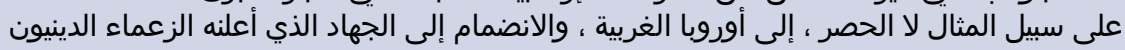

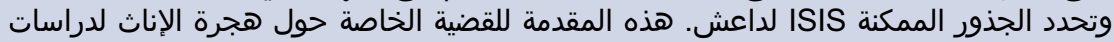

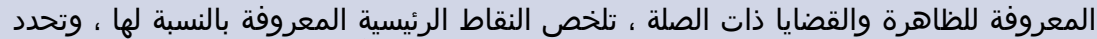

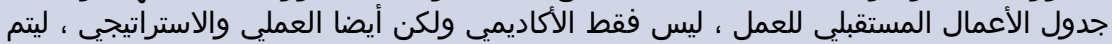
اتباعها.

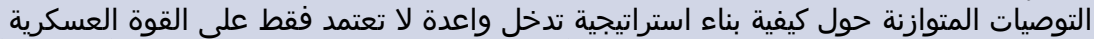

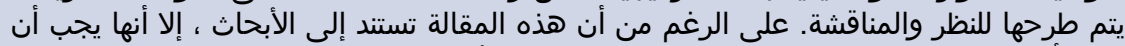

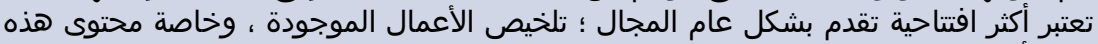

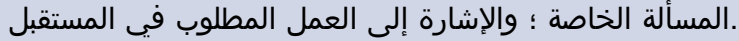

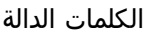

داعش ، تجنيد الإناث ، التحفيز ، قمع المسلمين ، الخلافة ، الاغتراب ، العزلة ، الإعادة إلى الوطن ، التدخلات 